Ann. Biol. anim. Bioch. Biophys., 1978, 18 (4), 819-823.

\title{
Hypothalamic lesions of goldfish : effects on gonadal recrudescence and gonadotropin secretion
}

\author{
par R. E. PETER, L. W. CRIM* \\ Depariment of Zoology, University of Alberta, \\ Edmonton T6G 2E9, Canada \\ * Marine Sciences Research Laboratory, Memorial University, St. John's A1C 5 S7 Canada
}

Summary. The effects of radiofrequency lesions of the nucleus lateral tuberis (NLT) and nucleus preopticus (NPO) on gonadal recrudescence and serum gonadotropin levels in male and female goldfish were investigated. Lesions destroying a substantial portion of the NLT caused a significant decrease in the gonadosomatic index in comparison to normal and sham-operated control groups. The ovary of NLT lesioned fish had a greater amount of atresia evident and recrudescence was frequently not as advanced as in the controls. Lesions in the NPO region also caused a decreased gonadosomatic index, but this was not found in other experiments. In the experiment in which NPO lesions were effective, ovarian recrudescence was generally at an earlier stage compared to controis. Serum gonadoiropin levels in male or female NLT or NPO lesioned fish were not significantly different from the levels found in normal or sham control groups.

\section{Introduction.}

Lesions in the nucleus lateral tuberis (NLT) of goldfish cause a decreased gonadosomatic index (Peter, 1970). The specific region of the NLT found to be involved is the NLT pars posterior and the posterior NLT pars anferior. Lesions in other regions, including the nucleus preopticus (NPO), had no effects. These results were interpreted to demonstrate involvement of the NLT in regulation of gonadal activity, presumably via secretion of a gonadotropin $(\mathrm{GHH})$ releasing factor $(\mathrm{GRH})$. The presence of GRH activity in crude extracts of the hypothalamus of goldfish (Crim et al., 1976) and other teleost species (for review see Crim ef al., 1976) supports the idea of a GRH center in the hypothalamus, although the origin of the activity was not localized in these studies. Contradictory to the idea of a hypothalamic origin for GRH, Goos and Murathanoglu (1977) have recently localized cells immunoreactive for luteinizing hormone-releasing hormone (LH-RH) in the telencephalon of rainbow trout. Since synthetic LH-RH has GRH activity in teleosts (for review see Crim et al., 1976), the localization of immunoreactive LH-RH cells in the telencephalon in the trout suggests that area as the origin for GRH activity. In the present study the effects of lesions in the NLT and NPO regions on GtH secretion and gonadal activity of goldfish were examined. 


\section{Materials and methods.}

Goldfish, common or comet variety, of $40 \mathrm{~g}$ average body weight were held in 96 I flow-through aquaria at $12-14{ }^{\circ} \mathrm{C}$, with a $16 \mathrm{hr}$ light-8 $\mathrm{hr}$ dark photoperiod, for the experiment. The fish were individually identified by a numbered tag attached to the operculum. Lesions were made with a radiofrequency current generator using $70-90$ volts and 0 insect pins insulated to within $0.5-0.6 \mathrm{~mm}$ of the tip. The electrodes were stereotaxically positioned using techniques previously described (Peter, 1970 ; Peter and Gill, 1975).

For blood sampling, the fish were anesthetized with tricaine methanesulfonate and about $0.3 \mathrm{ml}$ of blood taken by puncture of the caudal vasculature at between 2-4 hr after onset of the light period. Serum samples were collected and GtH concentrations determined by radioimmunoassay (Crim et al., 1976). At the end of the experiment the fish were killed by decapitation, and the brain rapidly dissected free and immersed in Bouin's solution, The gonads were also dissected, weighed, the condition noted, and then a segment of one gonad fixed in Bouin's solution. For the analysis of results the experimental fish were grouped according to the final lesion location as determined by histological examination. The $\mathrm{GtH}$ values for the various groups within an experiment were compared by Student's « $t$ » tests. The ovaries were histologically examined and the most advanced stage of oocyte development and the degree of atresia and/or ovulation noted, using the criteria of Yamazaki (1965) for the oocyte stages.

Table 1

Serum gonadotropin concentrations $(\mathrm{ng} / \mathrm{ml})$ and gonadosomatic index of female goldfish post-lesioning in the nucleus lateral tuberis (NLT) region or the nucleus preopticus (NPO) region

\begin{tabular}{|c|c|c|c|c|}
\hline \multirow{3}{*}{ Group } & \multicolumn{3}{|c|}{ Serum gonadotropin $(\mathrm{ng} / \mathrm{ml})$} & \multirow{3}{*}{$\begin{array}{c}\text { Gonadosomatic } \\
\text { Index }\end{array}$} \\
\hline & \multicolumn{3}{|c|}{ Days post-lesioning } & \\
\hline & 7 & 21 & 42 & \\
\hline $\begin{array}{l}\text { Normal } \\
(N=9)\end{array}$ & $0.70 \pm 0.16\left(^{a}\right)$ & $0.85 \pm 0.15$ & $0.98 \pm 0.18$ & $13.97 \pm 1.18\left(^{a}\right)$ \\
\hline $\begin{array}{c}\text { Sham } \\
(N=7)\end{array}$ & $4.82 \pm 3.21$ & $1.20 \pm 0.24$ & $1.06 \pm 0.21$ & $11.28 \pm 2.12$ \\
\hline $\begin{array}{c}\text { NLT } \\
(N=9)\end{array}$ & $4.04 \pm 2.66$ NS $\left(^{b}\right)$ & $1.75 \pm 0.96 \mathrm{NS}$ & $0.61 \pm 0.07 \mathrm{NS}$ & $5.70 \pm 0.83 \mathrm{~S}(c)$ \\
\hline $\begin{array}{c}N P O \\
(N=7)\end{array}$ & $9.07 \pm 7.16 \mathrm{NS}$ & $1.78 \pm 0.56 \mathrm{NS}$ & $1.50 \pm 0.38 \mathrm{NS}$ & $5.02 \pm 0.95 \mathrm{~S}$ \\
\hline
\end{tabular}

(a) mean \pm SE.

(b) NS = not significant compared to normal or sham control.

(c) $\mathrm{S}=$ significant compared to normal and sham control. 


\section{Results.}

Table 1 presents the data from female goldfish that were lesioned in the NLTaNLTp region in February and maintained for 42 days postoperatively. The period of February through April is the period of time during which female goldfish have rapid oocyte growth, with at least some oocytes being developed to the tertiary yolk globule (or granule) stage, ready to undergo the final maturation processes and ovulation. The lesions in the NLT and NPO regions both caused a significant decrease in the GSI. There were no significant differences in serum GtH levels between the normal, sham and lesioned groups at either 7, 21 or 42 days postoperatively. Oocytes were developed to the tertiary yolk globule stage in the normal and sham control groups. In the NLT and NPO lesioned groups, only three fish out of nine, and four out of seven, respectively, had oocytes at the tertiary yolk globule stage; other fish in these groups generally had oocytes only at the primary yolk globule stage. The NLT lesioned group had a greater prevalence of atretic oocytes.

Lesions in the NLT region of male goldfish also caused a significant decreased GSI and had no effects on serum GHH levels (table 2).

Table 2

Serum gonadotropin concentrations $(\mathrm{ng} / \mathrm{ml})$ and gonadosomatic index of male goldfish post-lesioning in the nucleus lateral tuberis (NLT) region

\begin{tabular}{|c|c|c|c|c|}
\hline \multirow{3}{*}{ Group } & \multicolumn{3}{|c|}{ Serum gonadotropin $(\mathrm{ng} / \mathrm{ml})$} & \multirow{3}{*}{$\begin{array}{c}\text { Gonadosomatic } \\
\text { Index }\end{array}$} \\
\hline & \multicolumn{3}{|c|}{ Days post-lesioning } & \\
\hline & 7 & 21 & 42 & \\
\hline $\begin{array}{c}\text { Normal } \\
(N=11)\end{array}$ & $0.96 \pm 0.20\left({ }^{a}\right)$ & $0.88 \pm 0.18$ & $0.65 \pm 0.11$ & $3.40 \pm 0.22\left({ }^{a}\right)$ \\
\hline $\begin{array}{c}\text { Sham } \\
(N=11)\end{array}$ & $0.72 \pm 0.17$ & $0.66 \pm 0.14$ & $0.63 \pm 0.10$ & $3.67 \pm 0.35$ \\
\hline $\begin{array}{c}N L T \\
(N=8)\end{array}$ & $1.99 \pm 0.88$ NS $\left({ }^{b}\right)$ & $0.59 \pm 0.15 \mathrm{NS}$ & $0.58 \pm 0.13$ & $2.57 \pm 0.25 \mathrm{~S}\left({ }^{c}\right)$ \\
\hline
\end{tabular}

(a) mean $\pm \mathrm{SE}$.

(b) NS = not significant compared to normal or sham control.

(c) $\mathrm{S}=$ significant compared to normal and sham control.

\section{Discussion.}

The lesions in the NLT region caused a decreased gonadosomatic index (GSI), blocked ovarian recrudescence and induced atresia. This confirms the earlier findings of Peter (1970) and supports an involvement of the NLT in secretion of GRH. However, no differences in serum GtH levels were found between the groups with lesions in the NLT region and the control groups. These results were confirmed in other experiments on females and males (Peter and Crim, unpublished results). 
In the present experiment lesions in the NPO region also caused a decreased GSI of female goldfish, blocked ovarian recrudescence and induced some degree of atresia. No effects on GtH levels were found in the NPO lesioned animals. This was the only experiment in which lesions in the NPO region had an effect on ovarian or testicular recrudescence (Peter and Crim, unpublished results). These results are, therefore, suggestive of some involvement of the NPO region in GRF secretion, but the results require confirmation.

A basic hypothesis about the relationship between blood levels of GtH and gonadal recrudescence is that there are incremental amounts of G+H in the blood in correlation with, and presumably to stimulate, progression of gonadal recrudescence. There is evidence in support of this hypothesis from some species (Breton et al., 1975 ; Crim et al., 1975). In the present work there were no significant differences in serum GtH levels between the fish with brain lesions and the control groups, even though oocyte development was generally at an earlier stage and atresia was occurring in the lesioned fish. This obviously does not fit with the above hypothesis. In recent work on the daily cycles of serum GtH in goldfish under different temperature-photoperiod combinations and at different states of gonadal activity (Hontela and Peter, unpublished results), if was found that serum GtH levels were basal and similar in fish at different states of gonadal activity for most of the $24 \mathrm{hr}$ period for fish held in cold water $\left(12^{\circ} \mathrm{C}\right)$ and on a long photoperiod (16L : 8D). The significant difference between fish with a regressed gonad and those undergoing recrudescence or with a mature gonad was that the latter each have a significant surge in $\mathrm{GtH}$ levels, indicating a surge in secretion, at between 8-12 hr after the onset of the light period. This may account for the lack of any differences in serum $\mathrm{GtH}$ between the lesioned fish and the controls in the present experiment since all blood samples were taken at between 2-4 hr after onset of the light period, a time when serum levels of $\mathrm{GtH}$ are basal. Preliminary results indicate that NLT lesions do alter the daily pattern of secretion of GtH in goldfish ; alteration of the daily pattern of secretion of $\mathrm{GHH}$ may be the basis for the observed effects of the NLT lesions on the gonads.

Symposium sur la Reproduction des Poissons Paimpont, France, 19-21 septembre 1977.

Acknowledgments. - We wish to thank Dr. E. Burzawa-Gérard and Dr. B. Breton for purification of carp gonadotropin used in the radioimmunoassays. This work was supported by grants A6371 to R. E. Peter and A9729 to L. W. Crim from the National Research Council of Canada.

Résumé. Nous avons étudié les effets de lésions du noyau latéral du tuber (NLT) et du noyau préoptique (NPO) sur le développement des gonades et le niveau de gonadotropine sérique chez le poisson rouge mâle et femelle. Les lésions qui détruisent une partie importante du NLT entraînent une diminution significative de l'index gonadosomatique par rapport aux animaux normaux et aux témoins qui ont subi une opération fantôme. L'atrésie est plus importante dans l'ovaire des animaux porteurs d'une lésion du NLT et le stade d'avancement de la gamétogenèse est souvent moins avancé que dans le groupe témoin. Les lésions dans la région du NPO entraînent également parfois une diminution de l'index gonadosomatique. Quand les lésions du NPO sont efficaces, la recrudescence ovarienne 
est en général moins avancée que chez les témoins. Les lésions du NLT ou du NPO n'entraînent pas de modifications du niveau de gonadotropine dans le sérum chez le mâle ef chez la femelle.

\section{References}

BRETON B., JALABERT B., FOSTIER A., BILLARD R., 1975. Ełude sur le cycle reproducteur de la truite arc-en-ciel et de la tanche. J. Physiol., Paris, 70, 561-564.

CRIM L. W., PETER R. E., BILLARD R., 1976. Stimulation of gonadotropin secretion by intraventricular injection of hypothalamic extracts in the goldfish, Carassius auratus. Gen. comp. Endocr., 30, 77-82.

CRIM. L. W., WATTS E. G., EVANS D. M., 1975. The plasma gonadotropin profile during sexual maturation in a variety of salmonid fishes. Gen. comp. Endocr., 27, 62-70.

GOOS H. J. Th., MURATHANOGLU O., 1977. Localisation of gonadotropin releasing hormone (GRH) in the forebrain and neurohypophysis of the trout (Salmogairdneri). Cell Tiss. Res., 181, 163-168.

PETER R. E., 1970. Hypothalamic control of thyroid gland activity and gonadal activity in the goldfish, Carassius auratus. Gen. comp. Endocr., 14, 334-356.

PETER R. E., GILL V. E., 1975. A stereotaxic atlas and technique for forebrain nuclei of the goldfish, Corassius auratus. J. comp. Neurol., 159, 69-102.

YAMAZAKI F., 1965. Endocrinological studies on the reproduction of the female goldfish, Carassius auratus L., with special reference to the function of the pituitary gland. Mem. Fac. Fish. Hokkaido Univ., 13, 1-64. 